\title{
An Investigation of Health Information Dissemination on Social Media: Content Analysis of CegahStunting Campaign on Instagram
}

\author{
$* 1^{\text {st }}$ Ida Nursanti \\ Department of Nursing \\ Universitas Jenderal Achmad Yani \\ Yogyakarta \\ Yogyakarta, Indonesia \\ ida@unjaya.ac.id
}

\author{
$2^{\text {nd }}$ Muhammad Rifqi Ma'arif \\ Pusat Studi dan Layanan Analitik Data \\ Universitas Jenderal Achmad Yani \\ Yogyakarta \\ Yogyakarta, Indonesia \\ rifqi@unjaya.ac.id
}

\begin{abstract}
Health information dissemination is one of the importance agendas on the public health sector. The effectivity on the way the health information was spread out plays a crucial-aspects on health habits on the society. In the case of stunting, right and concise information dissemination is very important to educate the citizen on how to prevent stunting in a proper-ways as early as possible. On the social media platform including Instagram, the stunting information dissemination was representing with a campaign employed the usage of \#CegahStunting hashtags. This article was tried to reveals how that campaign is going on so far, especially from the content preserved to the society related to stunting and its preventions. In this research, a large number of social media posts data from Instagram during 2018 and 2019 was collected for experimental purposes. Content analysis was then used as an approach for analyzing the collected data. We employed a computational-programs to performed content analysis task over the large Instagram post data containing \#CegahStunting hashtags. From the results, we can gather the dominant and also complimentary topics related to that the \#CegahStunting campaign on Instagram.
\end{abstract}

Keywords - stunting, health information dissemination, social media campaign, content analysis, Instagram

\section{INTRODUCTION}

Stunting is abnormal condition occurred by toddler or children indicated by the body height which is too for their appropriate age [1]. Indonesian Ministry of Health trough the regulation (Permenkes) number 1995/MENKES/SK/ XII/2010 define that a toddler classified as stunted (short) or severely stunted (very short) when their length or height are below normal comparing to his age based on Anthropometric Standard for Assessment of Child Nutritional Status [2]. In $2017,22,3 \%$ or approximately 150,8 million toddler all around the world suffered of stunting. Release from World Health Organization (WHO) in that year revealed that more than a half (55\%) stunting case report was come from Asia. From 83,6 million stunted toddler, nearly $60 \%$ comes from South Asia. In terms of proportion of stunted toddler to normal toddler, Indonesia was among three highest countries in South-East Asia Region with 36,4\% of their toddlers suffered of stunting [3]. Hence, stunting was becoming a serious problems that have to be consider as emergency situation and need serious prevention initiative.
In 2010, United Nation was launch Scaling Up Nutrition (SUN) program for accelerating the widespread of nutritious food around the world. Correspond to the SUN programme, Indonesian government through the Ministry of Health also started a national initiative to prevent stunting namely National Movement on Acceleration of Nutrition Improvement Program was conducted in the form of First Thousand Days of Life (1000 HPK). That initiative was implemented through specific and sensitive nutritional interventions performed by the health and and non-health sectors [4]. In order to educate the society about stunting and its prevention as well as disseminating the government initiative, The Ministry of Health have started a national campaign through mass and social media. One of the popular campaigns is the used of \#CegahStunting hashtag on social media, especially on Instagram. The aims of the campaign is for changing the Indonesian citizen behaviour related to the how they give nutritious food for toddler and pregnant woman by increasing their understanding about stunting. But unfortunately, according to the latest research conducted by Khatimah \& Laksmi [5] stated that the Indonesian citizen's knowledge of stunting and how to prevent it was relatively low. Therefore, there is a need to evaluate how the campaign on social media was going on so far.

Healthy life and environment is one of the most important aspect of human beings, thus health information becoming one of the most important information that should delivered properly throughout societies. Failing on managing the dissemination of health information lead to lack understanding of public or society about the crucial aspect of healthy life. Furthermore, those condition could potentially cause serious health problems such as malnutrition [6]. Nowadays, the emergence and rapid development of internet technology was significantly changed how the information spread, no exclusion of health information. By the rise and masive use of social media platform, any kinds of information can spread throughout the world in timely manner. Hence, social media platforms were gaining an important role in health information dissemination within the societies [7]. Moreover, the growing number of social media users in Indonesia was increased by $15 \%$ in early January 2019 [8]. That means that currently the number of social media users in Indonesia reached 150 milion people. Hence, the usage of social media could be considered as a game 
changing strategy for health information dissemination by allowing individual for taking more active role [9].

There a number of research related to the evaluation of social media usage for health information dissemination in Indonesia. Research conducted by Nugroho [10] tried to evaluate the effectivity of Facebook as social media platform for disseminating information about healthy reproduction for teenagers. Another research by Rahmah et.al [11] targetting the same social media platform as a benchmarks for the conventional campaign media for stop smoking campaign. However, those research are conducted in very limited environment with small amount of data. Thus, this research will employed a large number of social media conversation for providing more comprehensive investigation. In addition, this research will use Instagram as an object which investigation on this platform was relatively small comparing another famous social media platform likes Facebook and Twitter. Comparing to Facebook and Twitter, Instagram has more number what so called "millennial" users which actively use Instagram more frequent than the other two mentioned platforms. For the kind of health information dissemination especially about stunting and stunting prevention, the millennials could be considered as main object as they were on the verge of marriage time and shaping a new family. Hence, the proper stunting information would be one of the most information they should understand. Based on this background, this research is aims to exploring the use of Instagram as a tool for disseminating health information related to stunting treatment in Indonesia. In this article, an evaluation of how \#CegahStunting campaign on instagram was performed. Focus of the evaluation is on the content used within the campaign.

\section{METHOD}

\section{A. Dataset}

Dataset used in this research was acquired from Instagram was ranged within January 2018 to December 2019. Web scrapping technique implemented in Python programming language was employed for gathering the data automatically from Instagram. Web scrapping is a computational technique for automate the extraction of web content which could be publicly accessible [12]. During the aforementioned time window, approximately 10.160 Instagram posts which contain hashtag \#CegahStunting ware acquired. The time distribution of the acquired data between January 2018 to December 2019 is shown on figure 1. As shown in figure 1, the frequency of Instagram posts containing \#CegahStunting campaign is tend to increase as the time progress.

\section{B. Data Preprocessing}

Instagram posts which acquired and used in this research have three attributes namely Post Owner, Shared Images, Time, Post Caption and Post URL. Among those attributes, Post Caption was mainly used in this research which focused on the content analysis. Post Caption contains a textual description of shared images within a particular post. Before going further to the analysis parts, content data from Instagram need to be preprocessed due to the nature of social media data which were full of noise. Noise in social media or textual data included but not related to emoticon, special characters, number, stopword, punctuation etc. Those noise will significantly affects the analysis results if not maintained carefully. Hence, for clean or preprocess the acquired Instagram content data, a step by step preprocessing approach arranged by Hidayatullah \& Ma'arif [13] was employed on this experiments.

\section{Content Analysis}

Content analysis is an approach for revealing the presence of attributes likes words, phrase, themes, concept from textual data [14]. By employing content analysis, those attributes can be quantified for inferring the messages of certain textual documents. Source of the data could be in any form, from interviews to open questionnaire, notes to recorded conversation and written manuscript to text data from the internets like online news portal, conversation on social media and so on. Conceptual analysis is the basic type of content analysis. In conceptual analysis of certain textual information, the common procedure involves quantification of certain concept [15]. The aims of that conceptual analysis is for examining the presence key terms in the data. Even tough terms may be explicit or implicit, in this experiments we limit the discussion within explicit terms in forms of bigram and hashtag.

In this research bigram and hashtag was extracted from of \#CegahStunting's posts for the basis of content analysis. Bigram is a pair of words which shown is a sentence or post sequentially. By extracting bigrams from user posts we can have an insight the core concept of a message delivered within a certain text. By summarizing the most frequent bigram on posts related to \#CegahStunting campaign, we can analyze what the key information were delivered to the society about stunting prevention through Instagram. The second ingredients of content analysis used in this research is hashtag. Hashtag is a common concept in social media for emphasizing either explicit or implicit messages of text. By using hashtag, social media user tried to underlined the topic of their messages or posts. Analyzing the hashtag which cooccurently use with \#CegahStunting, we can summarize the topic or ideas of user messages which closely related to stunting prevention. In commonly social media platform a hashtag usually represented as individual unit of words that start with "\#” character. As additional analysis, we also present most popular post which containing \#CegahStunting hashtag.

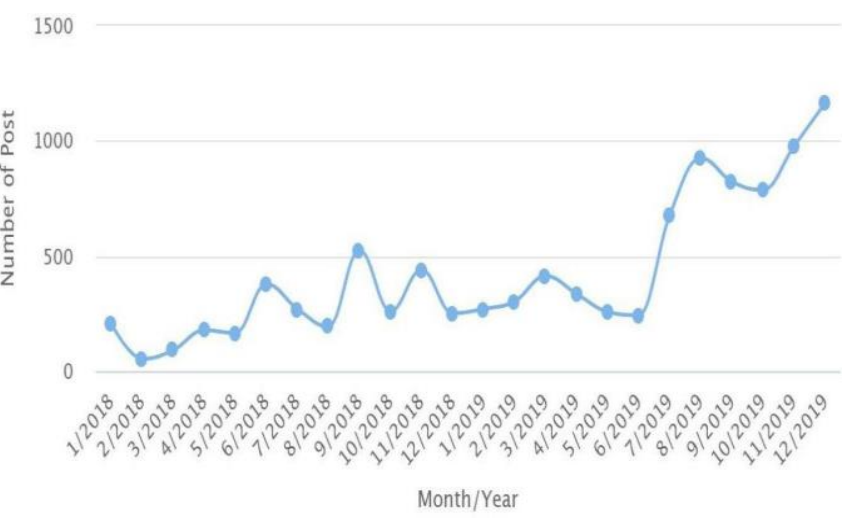

Fig. 1. Time distribution of \#CegahStunting post frequency on Instagram within 2018 and 2019 


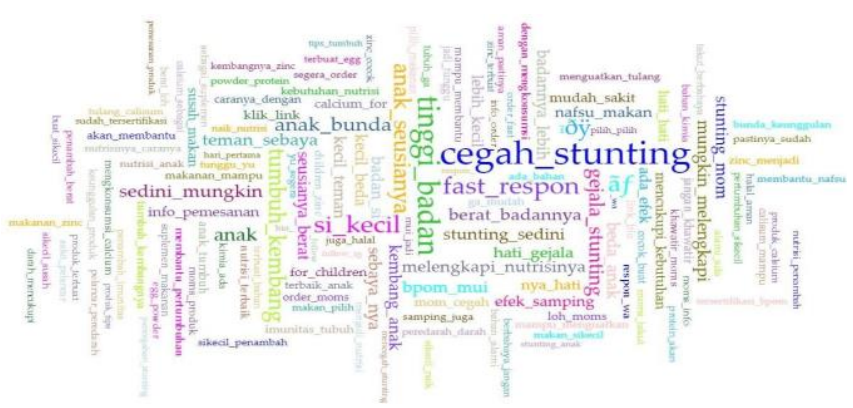

Fig. 2. Phares occurence frequency within \#CegahStunting posts on Instagram

\section{RESULT AND DISCUSSION}

\section{A. Frequent Bigram}

Figure 2 shows the bigram cloud. Bigram cloud is a variant of word cloud. Instead of individual word on word cloud, the bigram cloud shows the pair of words which forms a phrase. In figure 2, the more one particular bigram was appeared on \#CegahStunting's post, the bigger it's size on the bigram cloud. Hence, from the bigram cloud in figure 2, it can be illustrated what the dominant or highly frequent bigram found in the dataset of Instagram post related to \#CegahStunting campaign. Implicitly, those phrase reveals the messages of Instagram users, any concept which considered as important regarding stunting prevention.

From figure 2 we can show that phrase "Cegah Stunting" is significantly dominant among the others in accordance with the hashtag \#CegahStunting investigated in this research. Beyong the "cegah stunting" as the main bigrams, the first group of phares which frequently used within this campaign is "gejala stunting", "tinggi badan", "berat badan", "teman sebayanya" and "anak seusianya". Those phrases are closely related to the physical symptoms of stunting. The posts containing those phrase are trying to informs to the society how to early recognize, whether a kid is threated of suffering stunting or not. The next group of similar phrase which frequently appeared within \#CegahStunting's post is "mudah sakit" and "tumbuh kembang", those two phrase refers to the posts which contain a message about the consequence of stunting syndrome on kid and toddler.

Another terms with appear adequately significant within the bigram cloud is "sedini mungkin" and "melengkapi nutrisinya". Those two terms coined to the post content which emphasize on the importance of preventing stunting as early as possible by feed the toddlers with nutricious meals.

This information is actually the most important health information regarding stunting prevention. But unfortunately have a less post frequency comparing to the earlier groups of information. Moreover, those two phrase visually have a smaller size within the bigram cloud with the fourth group of phrases containing "info pemesanan" and "fast response" bigrams. The later phrases indicating an advertorial content which promoting nutritious food products.

\section{B. Frequent Hashtag}

The aim of analyzing hashtag which used alongside the main hashtag \#CegahStunting is to gain an roughly insight the proportion of topics contained within the campaign. Figure 3 illustrated the hashtag cloud to depict visual proportion of usage frequency of every hashtags recorded on the dataset. As a main hashtag, \#CegahStunting and \#Stunting appears significantly bigger than any others, hence the further discussion will focused on the other hashtags which written alongside \#CegahStunting. The analysis of the appeared hashtag will be discuss on later paragraph based on their visual size on the hashtagcloud depicted in figure 3.

The first group of hashtags having biggest visual size after \#cegahstunting was dominated by the hashtags related to the nutrition topics. The hashtags likes \#suplemenanak, \#nutrisianakterbaik, \#nutrisianaktiens and \#akuanaksgm lead to the posts which have content about nutritious food for kids and toddlers. But unfortunately, most of those posts are an advertorial post which emphasizing of their nutrition products rather than trying to educate the society how nutritious food could be a very important aspects in stunting preventions. Another group of hashtags with same visual size with nutrition related hashtags is \#anaksehat, \#tumbuhkembang and \#pertumbuhananak. Those hashtag was strongly correlated to the previously mentioned hashtags in which good nutrition was lead to proper development of kids and toddlers.

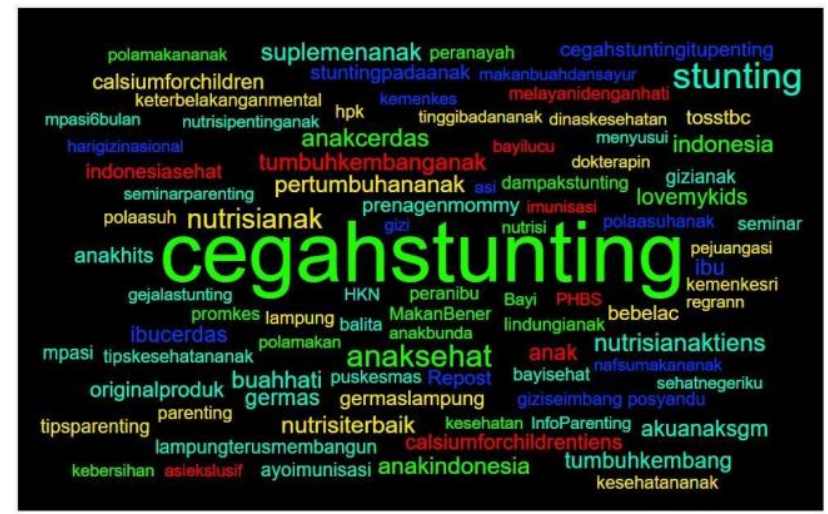

Fig. 3. Hashtag usage frequency within \#CegahStunting posts on Instagram

The next hashtags groups which have smaller visual size talked various topics. Hashtags like \#stuntingpadaanak, \#ibucerdas and \#cegahstuntingitupenting showed a posts containing which try to reveals the general symptoms of stunting. Topics related to nutrition also have an representation in this visual size of groups in hashtags likes \#calsiumforchildern, \#originalproduk and \#gizianak. Similar to the previous hashtags about nutrition, the revealed topics on this hashtags also contains advertorial information rather than educational content of nutritious foods for stunting preventions. Lastly, \#cegahstunting campaign also being a parts of more general health campaign in which its cooccurently appeared alongside \#germas, \#germaslampung and \#ayoimunisasi. But unfortunately, within our dataset the portion of the posts related to those hashtag was not significance in number. 


\section{Popular Post}

This sections discuss the most popular post based on the number of those post shared by Instagram users. The posts which have more than 15 shares outlined on table 1 were assumed as popular posts. From table 1, we can figure out that there are only 7 posts within our dataset which have number of shares as greater as 15. And the most popular posts was shared 793 times which is significantly far higher than the second most popular posts. From the table 1, all of the posts in rank 1 to 5 have the same topics on nutrition. This phenomenon reveals that so far, the campaign of stunting prevention used \#cegahstunting was dominated with nutrition related topics.

Figure 4 shows the image content of number 1 and 2 ranks of most popular posts in table 1 . The left picture which is the image of rank 1 post is kind of advertorial posts and significantly outperformed another posts in the number of share. There is nothing wrong with the advertorial posts as long as it the content is educative. But from the picture and the post captions attached, there is little information on how the nutritious food is very fundamental in stunting prevention, and more important how should it prepared and preserved. From the picture, we can assume that the advertorial content is far more dominated the educational content. Unlike the left picture, the right picture on figure 4, contains more educative information about nutritious food. But unfortunately, in terms of the number of share, that images far behind the left picture.

\section{TABLE I. MOST POPULAR POST OF \#CEGAHSTUNTING ON} INSTAGRAM

\begin{tabular}{clc}
\hline No & \multicolumn{1}{c}{ Excerpt of Post Caption } & $\begin{array}{c}\text { Number of } \\
\text { Shared }\end{array}$ \\
\hline $\mathbf{1}$ & $\begin{array}{l}\text { Tinggi badan si kecil beda dari anak } \\
\text { seusianya? Atau berat badannya lebih } \\
\text { kecil dari teman sebaya nya? Hati hati } \\
\text { gejala STUNTING mom. }\end{array}$ & $\mathbf{7 3 9}$ \\
\hline
\end{tabular}

\begin{tabular}{lll}
\hline 2 & $\begin{array}{l}\text { Haloo bunda, punya anak seusianya, } \\
\text { tapi tingginya tidak sama? Bisa jadi itu } \\
\text { gejala STUNTING (kurangnya asupan } \\
\text { nutrisi/gizi sejak kecil) }\end{array}$ & $\mathbf{7 7}$ \\
\hline $\mathbf{3}$ & $\begin{array}{l}\text { Apa itu Stunting? Stunting merupakan } \\
\text { kondisi gagal tumbuh pada anak akibat } \\
\text { kekurangan gizi kronis di usia 1000 hari } \\
\text { pertama }\end{array}$ & $\mathbf{2 6}$ \\
\end{tabular}

4 Ayah Bunda, sudah familiarkah dengan stunting? Stunting ini merupakan masalah kurang gizi kronis yang disebabkan oleh asupan gizi yang kurang

$5 \quad$ Tinggi badan adalah aset untuk buah hati di masa depannya. Cegah Stunting sedini mungkin dengan melengkapi nutrisinya
6 Menurut WHO, stunting adalah kondisi gagal tumbuh. Biasa dialami oleh anak yang mendapatkan gizi buruk dan

stimulasi psikososialnya tidak memadai.

$7 \quad$ Terimakasih mendukung acara

@pintarbelajar.id bersama "Stunting.

Kenali dan Cegah Sekarang Demi Generasi

Cemerlang Di Masa Depan"
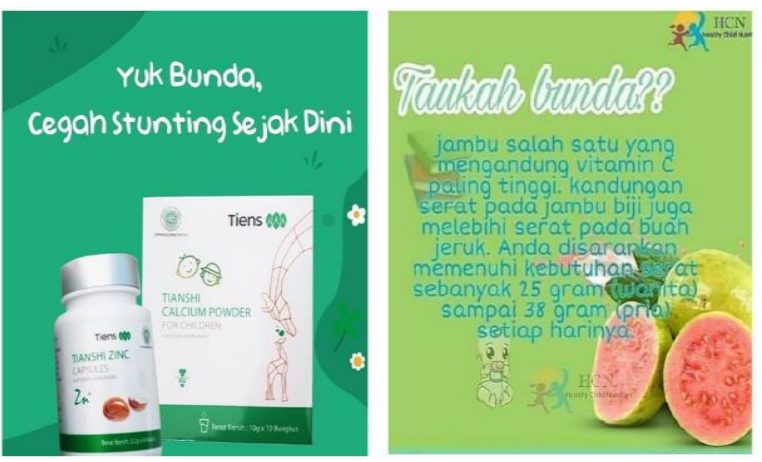

Fig. 4. Shared images of two most popular posts defined in table 1

\section{CONCLUSION}

We have successfully explore the messages behind the Instagram posts containing \#CegahStunting hashtags by applying simple content analysis approach on large-scale text data. The content analysis was done by revealing the bigram and hashtag which frequently used and visualize that using a term cloud. Those combination are suitable for gaining visual insight on how the stunting prevention campaign goes on especially on the content of the campaign. From the results, we reveals that the content of stunting prevention campaign with \#CegahStunting hashtags was significantly dominated by the posts which have topic about nutrition. But unfortunately, instead of educating the society the importance of nutritious food for preventing stunting, those posts are advertorial content which emphasize more on product promotion. There are very few posts which have comprehensive content on what is nutritious food and how to preserved it. Another hashtags which have less significant portion is related to general symptoms of stunting. Unlike the hashtags usage, bigram analysis another approach for content analysis on \#CegahStunting campaign reveals different perspective. From the bigram analysis, the dominant topic which talked by Instagram user is the symptoms of the stunting and followed by the topic of nutrition. This phenomenon is interesting and could be further investigated as future works.

\section{REFERENCES}

[1] A. J. Prendergast and J. H. Humphrey, "The stunting syndrome in developing countries," Paediatr. Int. Child Health, vol. 34, no. 4, pp. 250-265, Nov. 2014.

[2] Indonesian Ministry of Health, Peraturan Menteri Kesehatan No. 1995/MENKES/SK/XII/2010. 2016.

[3] Indonesian Ministry of Health, "Situasi Balita Pendek (Stunting di Indonesia)," Jakarta, 2018 
[4] E. Satriawan, "Strategi Nasional Percepatan Pencegahan Stunting 2018-2024," Jakarta, 2018.

[5] K. Khatimah and L. Laksmi, "Prevent Stunting Campaign: Dissemination of Health Information through Instagram," Rec. Libr. J., vol. 5, no. 1 , p. 80 , Oct. 2019.

[6] K. G. Dewey and K. Begum, "Long-term consequences of stunting in early life," Matern. Child Nutr., vol. 7, pp. 5-18, Oct. 2011.

[7] X. Gui et al., "Understanding the Patterns of Health Information Dissemination on Social Media during the Zika Outbreak," AMIA ... Annu. Symp. proceedings. AMIA Symp., vol. 2017, pp. 820-829, 2017.

[8] We Are Social, "Digital 2019: Indonesia," 2019.

[9] P. Sharma and P. D. Kaur, "Effectiveness of web-based social sensing in health information dissemination - A review," Telematics and Informatics, vol. 34, no. 1. Elsevier Ltd, pp. 194-219, 01-Feb-2017.

[10] C. V. Nugroho, "Pengaruh Pemberian Materi Kesehatan Reproduksi Melalui Grup Facebook Terhadap Pengetahuan Remaja," $J$. Promosi Kesehat., vol. 2, no. 2, 2014.
[11] Mi. Rahmah, H. Huriati, And A. Arbianingsih, "Perbedaan Efektivitas Pendidikan Kesehatan Media Facebook Dan Media Leaflet Terhadap Motivasi Berhenti Merokok Pada Remaja," J. Islam. Nurs., vol. 3, no. 1, pp. 62-70, Jul. 2018.

[12] V. Singrodia, A. Mitra, and S. Paul, "A Review on Web Scrapping and its Applications," in 2019 International Conference on Computer Communication and Informatics, ICCCI 2019, 2019.

[13] A. F. Hidayatullah and M. R. Ma'Arif, "Pre-processing Tasks in Indonesian Twitter Messages," in Journal of Physics: Conference Series, 2017, vol. 801, no. 1.

[14] C. Erlingsson and P. Brysiewicz, "A hands-on guide to doing content analysis," African Journal of Emergency Medicine, vol. 7, no. 3. African Federation for Emergency Medicine, pp. 93-99, 01-Sep2017.

[15] M. Bengtsson, "How to plan and perform a qualitative study using content analysis," NursingPlus Open, vol. 2, pp. 8-14, 2016. 